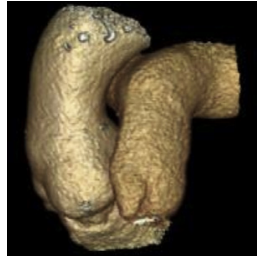

\section{AORTIC \\ HOMOGRAFTS: \\ SHOULD WE REALLY \\ LOSE THE \\ OPPORTUNITY?}

\section{To the Editor:}

We thank Crestanello ${ }^{1}$ for the precise analysis of our report. As rightfully stated, the results published on the long-term follow-up of cryopreserved allograft (CA) for aortic valve replacement drop a veil of uncertainty on the durability of allogenic tissue in the second decade after implantation, considering the increased rate of reoperation for structural valve degeneration and its associated risk. We agree that the use of CA should be tailored to certain categories of patients and indeed in our study the main indication for allograft implantation was infective endocarditis (IE). This reflects the guidelines from the Society of Thoracic Surgeons, ${ }^{2,3}$ which assigned a class IIb recommendation with a level of evidence B to the use of CA in IE. Aortic homografts are considered reasonable for native aortic valve endocarditis, particularly with periannular abscess and extensive annular or aortic wall destruction requiring aortic root replacement/reconstruction, or in cases of extensive aortic-ventricular discontinuity. ${ }^{4}$ The American Association for Thoracic Surgery 2016 guidelines ${ }^{5}$ echo these recommendations indicating $\mathrm{CA}$ for invasive and destructive native aortic valve IE requiring root reconstruction and replacement; however, a prosthetic bioroot or prosthetic valved conduit with a mechanical or bioprosthetic valve are considered acceptable alternatives, and the choice should be guided by surgeon training and experience. As we previously pointed out, the degree of infectious involvement of annulus and aortomitral curtain should drive the prosthesis choice and operative strategy, ${ }^{6,7}$ and in the guidelines the use of mechanical and stented xenograft is advocated in complex IE with periannular abscess when the valve can be anchored securely to healthy and strong tissue (class IIa level of evidence B). Conversely, an allograft or a biologic tissue root has been considered preferable to a prosthetic valved conduit in case of extensive annulus destruction, extra-aortic invasion, and when radical surgery with root reconstruction is required. ${ }^{4,5}$ The lack

\footnotetext{
The Editor welcomes submissions for possible publication in the Letters to the Editor section that consist of commentary on an article published in the Journal or other relevant issues. Authors should: • Include no more than 500 words of text, three authors, and five references. $\bullet$ Type with double-spacing. • See http://jtcs.ctsnetjournals.org/ misc/ifora.shtml for detailed submission instructions. • Submit the letter electronically via jtcvs.editorialmanager.com. Letters commenting on an article published in the JTCVS will be considered if they are received within 6 weeks of the time the article was published. Authors of the article being commented on will be given an opportunity of offer a timely response ( 2 weeks) to the letter. Authors of letters will be notified that the letter has been received. Unpublished letters cannot be returned.
}

of randomized evidence weakens the argument in favor of CA, but in the context of IE the rightly mentioned potential for $\mathrm{CA}$ degeneration is counterweighted by the benefit in terms of resistance to reinfection, which is an even more daunting problem.

In this context, evidence of the safety and durability of biological prostheses and homograft have been widely reported. Moon and colleagues ${ }^{8}$ showed a reinfection rate of $2 \%$ at 10 years after aortic valve replacement for IE, with the majority of recurrences occurring within the first year. When comparing with mechanical prosthesis, they showed an equal risk of reoperation between mechanical valves versus bioprosthesis regardless to the prosthesis type. Flameng and colleagues ${ }^{9}$ demonstrated a low recurrence of endocarditis in homograft even in complex cases, and these results were confirmed by Svensson and colleagues, ${ }^{10}$ who suggested the long-term durability and safety of CA with the additional benefit of the best postoperative hemodynamic parameters and favorable ventricular remodeling. Finally, in prosthetic valve endocarditis, survival when using a homograft is higher than in prosthetic valves (5-year cumulative survival $88 \%$ vs $66 \%)^{11}$

Structural valve degeneration is surely an issue that demands further research and we are currently investigating the avoidance of cryopreservation by keeping the homograft in culture media at $4^{\circ} \mathrm{C}$ to reduce the risk of degeneration; however, is this risk enough to lose the opportunity to provide especially young patients with a biological valve conduit with excellent hemodynamic parameters, that does not require anticoagulation therapy, and even prevents further relapses of infections?

Francesco Nappi, $M D^{a}$
Cristiano Spadaccio, MD, PhD ${ }^{b, c}$
Massimo Chello, $M D^{d}$
${ }^{a}$ Department of Cardiac Surgery
Centre Cardiologique du Nord de Saint-Denis
Paris, France
${ }^{b}$ Department of Cardiothoracic Surgery
Golden Jubilee National Hospital
Glasgow, United Kingdom
${ }^{c}$ University of Glasgow Institute of Cardiovascular and
Medical Sciences
Glasgow, United Kingdom
department of Cardiovascular Surgery
Università Campus Bio-Medico di Roma
Rome, Italy

\section{References}

1. Crestanello JA. Aortic homografts: unrealized expectations and hard reoperations at the end. J Thorac Cardiovasc Surg. 2018;156:1351-2.

2. Savage EB, Saha-Chaudhuri P, Asher CR, Brennan JM, Gammie JS. Outcomes and prosthesis choice for active aortic valve infective endocarditis: analysis of 
Authors have nothing to disclose with regard to commercial support.
Author has nothing to disclose with regard to commercial support.
The Society of Thoracic Surgeons adult cardiac surgery database. Ann Thorac Surg. 2014;98:806-14.

3. Byrne JG, Rezai K, Sanchez JA, Bernstein RA, Okum E, Leacche M, et al Surgical management of endocarditis: the Society of Thoracic Surgeons clinical practice guideline. Ann Thorac Surg. 2011;91:2012-9.

4. Byrne JG, Rezai K, Sanchez JA, Bernstein RA, Okum E, Leacche M, et al. Surgical management of endocarditis: the Society of Thoracic Surgeons clinical practice guideline. Ann Thorac Surg. 2011;91:2012-9.

5. AATS Surgical Treatment of Infective Endocarditis Consensus Guidelines Writing Committee Chairs, Writing Committee. 2016 the American Association for Thoracic Surgery (AATS) consensus guidelines: surgical treatment of infective endocarditis: executive summary. J Thorac Cardiovasc Surg. 2017; 153:1241-58.e29.

6. Nappi F, Spadaccio C. Simplest solutions are not always the cleverest: can we stitch in an infected annulus? Should we rethink the current guidelines? J Thorac Cardiovasc Surg. 2017;154:1899-900.

7. Nappi F, Spadaccio C, Acar C. Use of allogeneic tissue to treat infective valvular disease: has everything been said? J Thorac Cardiovasc Surg. 2017. 153:824-8.

8. Moon MR, Miller DC, Moore KA, Oyer PE, Mitchell RS, Robbins RC, et al. Treatment of endocarditis with valve replacement: the question of tissue versus mechanical prosthesis. Ann Thorac Surg. 2001;71:1164-71.

9. Flameng W, Daenen W, Jashari R, Herijgers P, Meuris B. Durability of homografts used to treat complex aortic valve endocarditis. Ann Thorac Surg. 2015;99:1234-8.

10. Svensson LG, Pillai ST, Rajeswaran J, Desai MY, Griffin B, Grimm R, et al. Long-term survival, valve durability, and reoperation for 4 aortic root procedures combined with ascending aorta replacement. J Thorac Cardiovasc Surg. 2016; 151:764-74.e4.

11. Perrotta S, Jeppsson A, Frojd V, Svensson G. Surgical treatment of aortic prosthetic valve endocarditis: a 20-year single-center experience. Ann Thorac Surg. 2016;101:1426-32.

https://doi.org/10.1016/j.jtcvs.2018.11.024

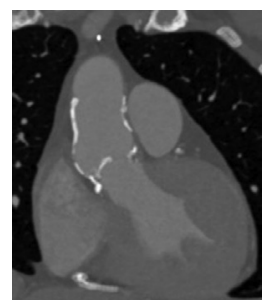

\section{NO, WE SHOULD NOT \\ LOSE THE \\ OPPORTUNITY, BUT \\ WE NEED ADDITIONAL \\ RESEARCH \\ Reply to the Editor:}

The letter of Nappi and colleagues ${ }^{1}$ in response to my editorial commentary ${ }^{2}$ on their article $^{3}$ is entitled "Aortic Homografts: Should We Really Lose the Opportunity?" My answer to their question is "No, we should not." Cryopreserved aortic homograft should be in the armamentarium of every surgeon who treats patients with endocarditis. But the real question is "Are we benefiting patients with aortic root endocarditis by replacing the root with a cryopreserved homograft?" My answer to this question is "We don't know, additional evidence to support the theoretic advantages associated with its use is needed." The original report of Nappi and associates $^{3}$ on 210 patients is an important contribution to the field. As Nappi and colleagues ${ }^{1}$ point out in their letter, the evidence for or against the use of cryopreserved aortic allografts comes from nonrandomized, retrospective, observational studies (level of evidence B). Although many prestigious authors advocate their use, others have found no benefit relative to prosthetic valve conduits in terms of cure rate, infection recurrence, durability, and reoperation. ${ }^{4,5}$ My impression is that the key concept for the treatment of endocarditis is radical débridement of all the infected tissue, with the reconstruction method likely less important. ${ }^{6}$ Some of the advantages of homograft relative to prosthetic valve conduits are technical and difficult to quantify in a clinical trial, such as the use of the anterior leaflet of the mitral valve for root reconstruction. Other claimed advantages, such as improved cure rate and increased resistance to infection, need to be demonstrated conclusively. Additional research on tissue preservation strategies is also necessary to prevent calcification and prolong homograft durability. This necessary evidence will prevent us from "losing the opportunity" and advance our knowledge on the best reconstruction strategy for extensive aortic root endocarditis.

Juan A. Crestanello, MD Department of Cardiovascular Surgery Mayo Clinic Rochester, Minn

\section{References}

1. Nappi F, Spadaccio C, Chello M. Aortic homografts: should we really lose the opportunity? J Thorac Cardiovasc Surg. 2019;157:e245-6.

2. Crestanello JA. Aortic homografts: unrealized expectations and hard reoperations at the end. J Thorac Cardiovasc Surg. 2018;156:1351-2.

3. Nappi F, Nenna A, Petitti T, Spadaccio C, Gambardella I, Lusini M, et al. Long-term outcome of cryopreserved allograft for aortic valve replacement. $J$ Thorac Cardiovasc Surg. 2018;156:1357-65.e6.

4. AATS Surgical Treatment of Infective Endocarditis Consensus Guidelines Writing Committee Chairs, Pettersson GB, Coselli JS; Writing Committee, Pettersson GB, Coselli JS, et al. 2016 the American Association for Thoracic Surgery (AATS) consensus guidelines: surgical treatment of infective endocarditis: executive summary. J Thorac Cardiovasc Surg. 2017;153:1241-58.e29.

5. Byrne JG, Rezai K, Sanchez JA, Bernstein RA, Okum E, Leacche M, et al. Surgical management of endocarditis: the Society of Thoracic Surgeons clinical practice guideline. Ann Thorac Surg. 2011;91:2012-9.

6. David TE, Gavra G, Feindel CM, Regesta T, Armstrong S, Maganti MD. Surgical treatment of active infective endocarditis: a continued challenge. J Thorac Cardiovasc Surg. 2007;133:144-9. 